\title{
The Impact of Provincial Forest Subsidies on Deforestation in Indonesia
}

Trisnu Surandoko ${ }^{1}$

Submitted: July 27 $2021 \mid$ Accepted: October $23^{\text {rd }} 2021 \mid$ Published: October $31^{\text {st }} 2021$

\begin{abstract}
This study investigates the impact of the forest subsidy on the deforested areas. Panel data were used to examine whether the forest subsidy and the logging tariff policy could curb the province's deforested area from 2009 to 2019. Pooled OLS was the suitable model to estimate the relationship. The study found an unexpected result: increased forest subsidy increased the deforested area in a province. At the same time, the increase in industry-manufacturing sector workers reduced the deforested area. Another unpredictable result was that the logging tariff, which was expected to reduce deforested areas, did not affect the deforested areas in a province.
\end{abstract}

Keywords: deforested area; forest; subsidy; tariff; policy

Subject: Natural resource and environmental policies

\footnotetext{
${ }^{1}$ Master of Economic Planning and Development Policy, Faculty of Economics and Business, Universitas Indonesia, Depok, Indonesia
} 


\title{
The Impact of Provincial Forest Subsidies on Deforestation in Indonesia
}

\author{
Trisnu Surandoko
}

\section{Introduction}

In the practice of Decentralization in Indonesia which began in 1999, the central government has delegated full forest management authority to the local governments. This implies that the actual owner of the forest area is the local government. Therefore, the responsibility for forest management lies with the local government. For instance, the central government gives local governments full authority of mining and plantation permit issuance. Thus, the local governments in Indonesia are competing to utilize their forests for economic interests such as mining, agricultural land, and plantations. However, since decentralization began, not all local governments have undertaken forest conservation. Studies show that decentralized practices have led to deforestation at the local government level (Adrison 2013).

Deforestation is a public problem because it brings real threats to human life, such as losing clean air, diminishing ecosystems, and drought (Bettwy 2005; Kelly 2013; Robbins 2015). These causes are linked to deforestation in Indonesia. However, the Indonesian government continues to strive to preserve the environment from deforestation. The central government makes a national policy that all new and old government policies in all sectors must support environmental sustainability. A study shows that governments do not just stand by and see their forests destroyed. For example, the Brazilian government issued public policies such as limiting the supply chain of agricultural products to reduce the rate of deforestation (Nepstad et al., 2014). Although forest restoration with a reforestation program takes a long time, one study reveals the success of the reforestation program from Ashton et al., 2014. Their research results indicate that the outcomes of reforestation can produce vegetation that resembles a natural forest.

Indonesia has vast natural forests and is one of the countries with the most significant natural forest globally. In 2020, Indonesia still had 125.9 million ha of forests (Statistics Indonesia 2020). Unfortunately, around 0.4 million ha of natural forests in Indonesia are damaged every year (Indonesia 2020). Furthermore, the rate of deforestation in Indonesia is around $0.48 \%$ per year (Anugrah 2020b). From these facts, we can calculate that in the next 300 years, Indonesia will not have any forests if the country does not take specific steps. This calculation reminds us that Indonesia has a vital role globally, namely as a world oxygen contributor. This reminds us of the importance of Indonesia's forests in the world. However, forest management practices in Indonesia, dominated by economic motives, still conflict between policies that care about the environment and provide welfare for the community (Erwinsyah et al., 2013).

The results of one previous study showed a link between deforestation and regional economic activity (Adrison 2013). This study estimated the relationship between democracy, decentralization, and deforestation. However, Adrison did not include the incidence of policy changes regarding the decentralization system in 2014 and a new logging tariff policy on forest management from 2014 to 2019 . The effect of changes in forest management authority 
from local government to provincial government level has not been tested. Furthermore, the government policies in the form of imposition of the raise in logging tariff in 2014 have been expected to increase the deforestation.

This research will fill in the gaps regarding the changed authority over forest area management and the imposition of new logging tariff policies that have not been tested in decentralization and deforestation studies. Moreover, this study will include the new variable namely, forest subsidy, agriculture sector, plantation sector worker, mining sector worker, industry sector worker, population density, and compliance to the logging tariff policy to curb the rate of deforestation. This research can help the Indonesian government evaluate the sustainability of the forest reforestation subsidy program. Knowing how significant the impact of the forest subsidy given to the provincial government on the deforestation area will make it easier to decide whether the program will continue.

Research carried out even earlier by Mildrayana (2012) looks at the socio-economic conditions of the region on deforestation in Indonesia. He used Indonesian national survey data from 2003 to 2010 and chose several economic indicators as factors that influence deforestation. Mildrayana found that the socio-economic conditions affected, but not as much as regional economic activities. Unexpectedly, he found that the forest concession is more threatened by logging activities because of the economic activities carried out in the regions. He also found that several government regulations had controlled these economic activities, but the unclear action and control of the logging activities triggered deforestation.

The decentralized system in Indonesia has resulted in a significant shift in the central government spending to the regional governments, namely municipality/districts and provinces. This spending cost a budget about one-third of the total state budget. However, this fiscal decentralization is still accompanied by political issues because the regional financial strength is still heavily dependent on funding from the central government (Gonschorek and Schulze 2018). Gonschorek and Schulze examined the intergovernmental fiscal transfer system in Indonesia. They assessed the extent to which the current fiscal administration policy has shifted its stance to the fiscal decentralization policy. They critically evaluated the effectiveness and efficiency of the existing decentralized system, including the reforms of the decentralized system that were recently implemented.

They found that the intergovernmental fiscal transfer system in Indonesia does not have a grand plan. However, several incoherent systems consisting of various schemes were triggered for various reasons. They also found an issue of devolved property taxes, local own-source income remains low, which may partly be due to a lack of incentives to collect taxes, which is because they reduce General Fund transfers, and also because of a lack of a tax base. They briefly suggested that the own-source revenue of the region needs to be replaced by a reasonable estimate of potential own-source revenue to remove disincentives for revenue mobilization, and the Special Allocated Fund needs to be included in the calculation of fiscal capacity. The determination of financial needs in the General Fund formula must also be reformed, as it is unclear to some extent. Forest reforestation funds are part of this special allocated fund from the central government to carry out reforestation activities by the local governments.

Forest subsidies are part of Indonesia's decentralization program. Forest subsidy was thought to impact the deforested area because it is a source of funds for the reforestation 
program, which is an activity to restore the function of the deforested forest. From those several previous studies, no studies used forest subsidy as a determinant of deforestation.

Using the pooled OLS model, previous research related to deforestation was carried out by Anastatica (2020) with the variable interest of the forest management units and the Special Allocation Grant. She chooses the OLS model and results in one of her interest variables significantly affecting the dependent variable. However, she found that the primary interest variable did not affect the dependent variable at the .05 significance level. She found that a special allocation grant has no impact on deforestation.

Indonesia, as a developing country, uses forests as an asset to develop the economy. Indonesia performs decentralized forest management in its forest management like most countries in south and southeast Asia (Balooni and Inoue 2007). Balooni and Inoue found that the inability of the state to prevent degradation of forest resources or decrease in forest cover was due to the decentralized system of forest management by local-level governments.

This inability to prevent degradation occurs because of a lack of state accountability, financial and human resources, and the low priority given to forest resource development. Balooni and Inoue also found the inability of local communities to carry out long-term forest improvement programs themselves without technical support from experts from the central government. To achieve effective decentralized forest management, they promote collective efforts of all levels, including local, regional, national, and international stakeholders - the role of the forest management unit held by the Indonesian Ministry of Environment and Forestry.

The forest management unit evaluates forest destruction control programs. There has been no evaluation through previous studies that use a policy to increase timber logging rates to determine forest deforestation. In addition, population density as the cause of forest deforestation is still an important issue to study because it shows an inconsistent relationship with forest deforestation.

Previous research used a special allocation grant with a broad meaning as a determining factor in the deforested area. The special allocation grant in the previous research did not specifically use the funds intended for forest improvement or economic activities. This research uses part of the special allocation grant specifically for forestry funds and the objectives of the forest reforestation program. This more specific type of fund for forest reforestation programs has not been used in previous research to determine the extent of deforestation.

A research carried out by Yazid (2020) empirically tested several determinants of deforestation at the village level in Indonesia. Some of the variables tested were included income from the plantations, the use of firewood, burning land habit, non-wood small industries, a total of forest release, and the number of logging firms. Yazid found that villages with plantation as the primary commodity significantly affected the increase in deforestation. However, unexpectedly, he also found that burning the land and non-wood small industries has no effect of deforestation. Even the activities of logging companies show a negative relationship with the increase in the area of deforestation.

Many tropical forest countries are trying to combat deforestation of their forests by using government policies. Previous studies examined the effectiveness of those policies 
by linking agricultural censuses and the remote sensing data on deforestation and the degradation of the forest (Godar et al., 2014). The studies found that the implemented deforestation policies did not work to address all actors equally. Godar et al. suggested better monitoring to detect small-scale deforestation and a shift towards more incentivebased conservation policies. The research suggested that reducing deforestation is likely to be increasingly expensive and requires a tailored approach to the underlying actors.

Another study that examined incentive policies for deforestation carried out by examining issues of environmental change issues, particularly in Australia's carbon framing policy (Evans 2018). Evans examined landowners in Australia and explains how the effectiveness of incentives for reforestation depends on a mix of complementary instruments, including the provision of clear, accessible, and reliable information and institutional arrangements that prevent further deforestation. She found that restoring degraded and deforested landscapes can provide many environmental, food security, social and economic benefits to communities.

However, Evans also found that implementing large-scale re-forestation requires governance interventions that can effectively motivate landowners. In addition, she suggested that the effective incentives for reforestation should be supported by a coherent and complementary policy mix. The policy should include experiences from carbon agriculture policies that promote reforestation in, the production landscapes; experiences on landowner adoption; and a growing literature highlighting the potential benefits of assisted natural regeneration that being applied to large-scale reforestation.

Previous research used the type of production activity to measure the effect of economic activity of the deforested area. This research explicitly uses the number of workers in the economic sector, which is dominant in deforestation. This standardized economic sector worker variable per thousand has never been used in previous studies.

Since 2020, the Indonesian government has received a payment to reduce the deforestation rate by USD 103.8 billion from the Green Climate Fund (GCF) organization. Indonesia was considered as consistently reducing its annual deforestation rate (Anugrah 2020a). Indonesia's deforestation rate for the past ten years shows a downward trend (figure 1).

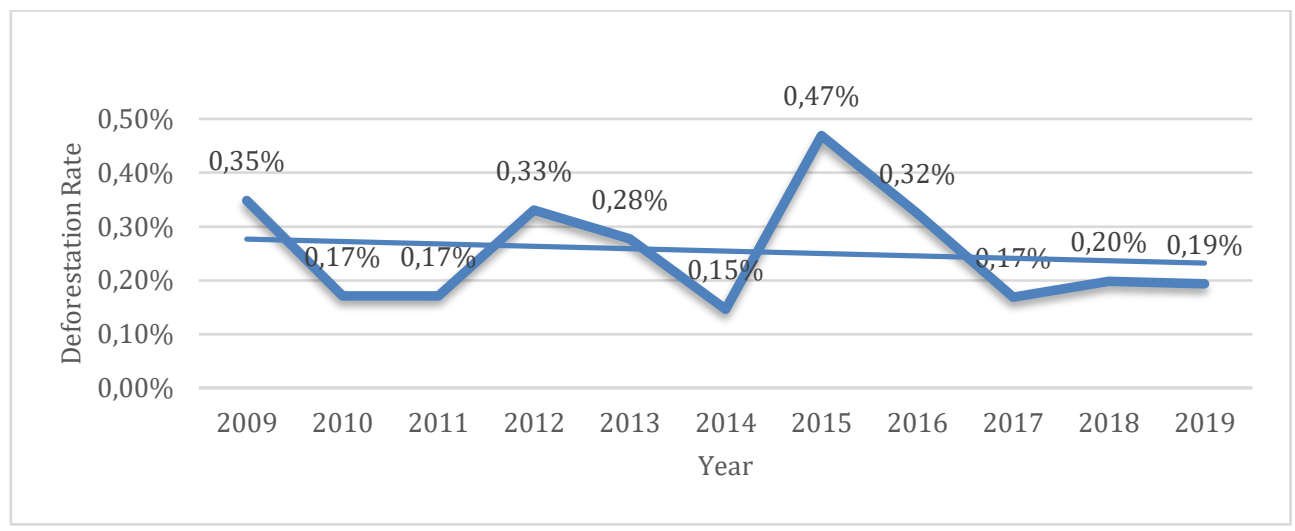

Figures 1 Deforestation rate in Indonesia 2009 to 2019 
Indonesia was also considered successful in making policies that support environmental sustainability. According to the Minister of Environment and Forestry of Indonesia in the same press conference, this success was not a one-sided claim. However, it had been verified by an independent team from United Nations Framework Convention on Climate Change (UNFCCC). The size of Indonesia's deforestation area in 10 years (Figure 2).

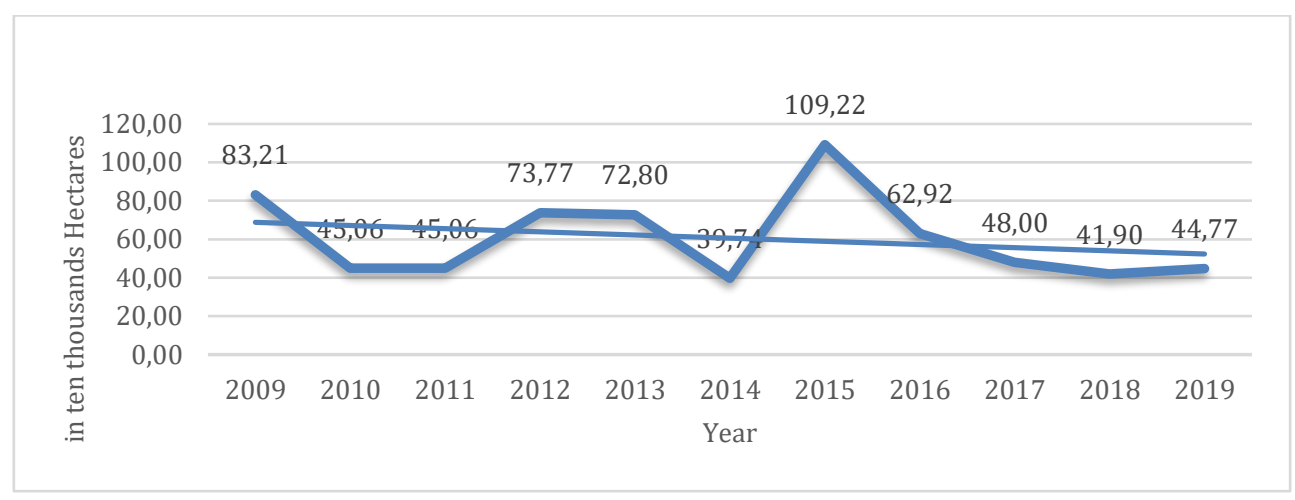

Figures 2 Deforestation area in Indonesia 2009 to 2019

Indonesia's forests that must be rehabilitated are still very large, around 13.36 million hectares (Susetyo, 2021). According to Susetyo, this area is equivalent to Java, Madura, and Bali Island. At the same time, the government's ability to finance reforestation and forest rehabilitation is only around 200 thousand hectares per year. This, not proportional to the annual rate of deforestation, is still relatively high, around 450 thousand hectares per year. Indonesia sees this as two sides of a coin, in which reforestation offsets deforestation. This means that reforestation, in forest areas that have been damaged by deforestation, is in the form of replanting the timber plants in ex-logging and mining areas.

The central government organizes forest rehabilitation through the Minister of Environment and Forestry. One of the goals of forest rehabilitation is to restore the functions of forests. This is subjected to the sustainability of the forest to be able to maintain again. The form of forest rehabilitation program activities is forest reforestation. Forest reforestation can be done by all levels of government, both central and local. However, every person or entity that manages and utilizes forests is obliged to reforest forests for the preservation and sustainability of forests.

The central government provides a forest fund, in the form of forest subsidy, known as a Reforestation Fund. Reforestation Fund is a fund for conducting reforestation, rehabilitation, and supporting activities collected from Business Permit Holders for Utilization of Forest Products from natural forests. These funds were collected from Business Permit Holders according to their forest utilization activities. Then, the funds are collected by the central government. The central government then allocates these funds to the Ministry of environment and forestry and local governments to carry out forest rehabilitation.

The source of funds for reforestation in Indonesia comes from forest management permit holders. Following the applicable forestry regulations, these funds are collected from the holder of a business permit to utilize forest products in the form of wood (President 
Indonesia 1999). The funds are then re-used again to finance the reforestation activities and supporting activities according to government regulations concerning reforestation and the rehabilitation of forest areas (President Indonesia 2020). This reforestation fund is the foundation of the government in rehabilitating damaged forests. In distributing this reforestation fund, the government allocates $40 \%$ of the existing funds for the central government and $60 \%$ of local governments.

The calculation of the allocation of reforestation funds carried out by the central government is under the control of the Minister of Finance, particularly the Directorate General of Central-Regional Financial Balance. The Directorate General of Fiscal Balance calculates the allocation of reforestation funds each year. Furthermore, the central government determines the allocation through a minister of finance regulation. The allocation of reforestation funds is then transferred from the central government directly to regional government accounts. The allocation of reforestation funds from the central government to local governments from 2009 to 2019 showed in figure 3 below.

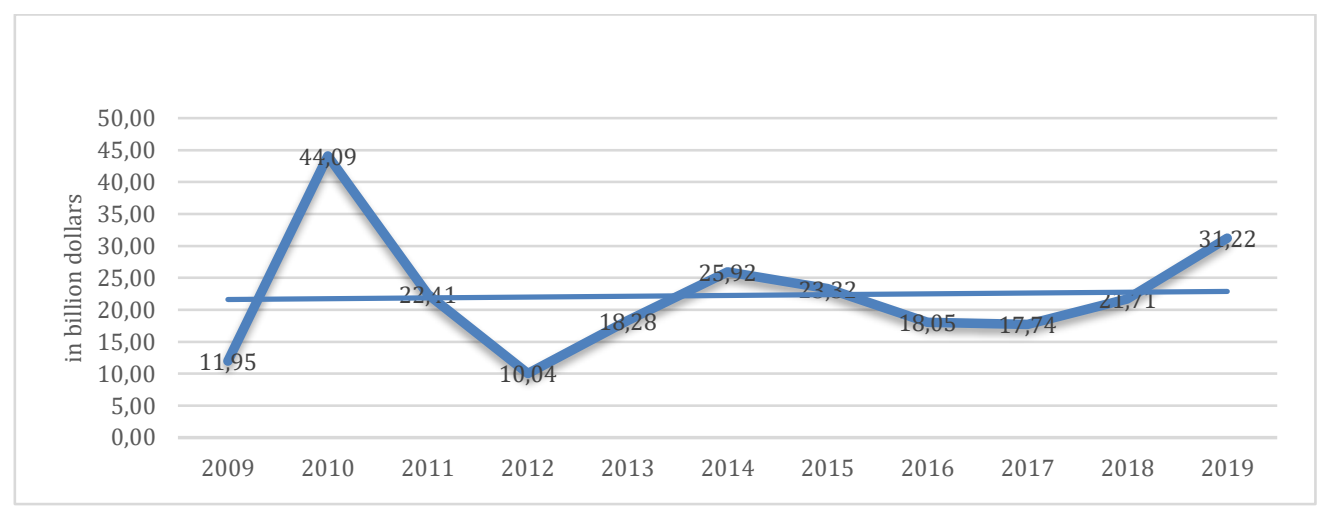

Figures 3 Reforestation Fund Allocation Trend 2009 - 2019

The allocation of reforestation funds takes into account the area of forest in each province. The proportion of the allocation of funds provided reflects the ratio of forest area between the existing provinces. In addition, the funds allocated can provide an overview of the forest destruction that has occurred there. However, the province's reforestation fund allocation does not reflect the magnitude of the provincial government's efforts to restore their deforested forest. The allocation of reforestation funds from the central government to local governments per province from 2009 to 2019 showed in figure 4 below. 


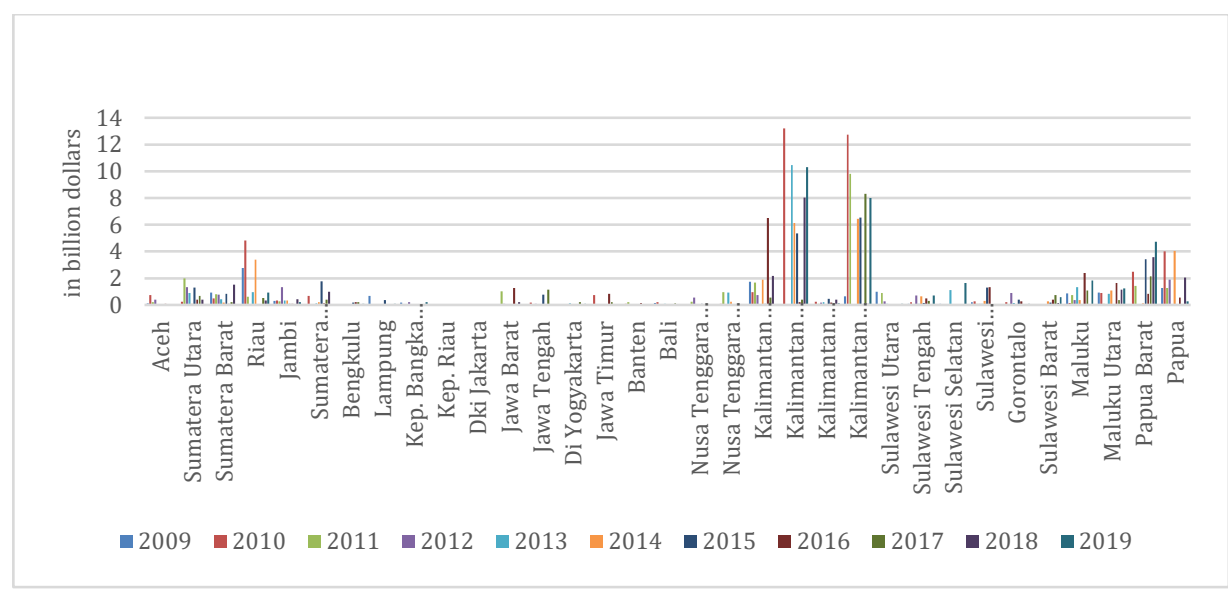

Figures 4 Reforestation Fund Allocation Trend 2009 - 2019 per Provinces

Logging activities are the cause of deforestation. These activities have an intensity that tends to increase. This is because the demand for wood, both from within and outside the country, is continually increasing. The demand for wood increases because Indonesia's timber forests are certified sources of the world's timber commodity. This is a concern to the government because the increased logging activities were suspected to the increasing deforestation areas. The central government then attempted to control deforestation through regulations on logging tariffs.

A logging tariff is a levy of money on forest managers and users' amount and type of woodcut. The object of levies, from logging tariffs, is all types of wood in Indonesian forests and are scattered throughout the province. The levy is calculated based on the type and quantity of woodcut by the business permit holder. The central government accommodates charges from business permit holders as non-tax state revenue from forest resources. From the wood industry, this revenue then becomes a source of funds for repairing the deforested forests. One of the objectives of this reallocation of funds is the forest reforestation program conducted by the local government.

This reforestation program was expected to offset the deforestation, that occurs due to the logging activities. However, the logging activities were strongly influenced by the demand for wood in the timber commodity market. The central government always tries to reduce logging, which causes deforestation, by increasing the logging tariff. To balance the increasing demand for timber, the government raised the logging tariff value in 2014.

\section{Method}

This research uses officially published data from Statistics Indonesia (BPS), The Ministry of Finance of The Republic of Indonesia, and the Ministry of Environment and Forestry in 2019. Data on forest subsidy allocation by Indonesia's central government was obtained from the Minister of Finance Regulation. Furthermore, the deforestation data were extracted from the geographical information system (GIS) of the Ministry of Environment 
and Forestry. Data on workers in the mining, agricultural, and plantation sectors were derived from Statistics Indonesia.

The definition of deforestation, according to the prevailing regulations in Indonesia, is forest loss. The deforested areas are defined as permanent changes from forested to non-forested areas. The calculation of deforested areas was done by calculating the changes in forest area lost in one year. For example, deforestation in 2010 is the area of land cover in 2009 minus the land cover area in 2010. The total change in the form of the area that is lost is called the deforested area. The land cover, on which the calculation is based, has considered the additional forest area from reforestation activities. The deforested area unit was expressed in a thousand hectares. The deforestation areas' data were reported by the satellite imagery of the Ministry of Forestry. The imagery result becomes the basis for calculating changes in the value of deforested areas.

The first independent variable is the amount of forest subsidy allocation. This variable reflects the provincial government's effort to restore its forest condition and function to its best condition. Furthermore, the capacity of these provincial governments may reflect their strong desire to restore degraded forests. This variable uses Indonesian currency (in trillions of Rupiah) as the unit of measurement, and it was expected to have a negative relationship to the deforested area.

The second variable is the implementation of new tariff policies since 2014. The new policy, in the form of increased tariffs, applied for all types of logging activities. This new tariff imposition was expected to reduce the logging activities to reduce the rate of deforestation. This variable is coded o for the year before 2014 and 1 otherwise. The implementation of this policy was expected to have a negative relationship with the deforested areas.

The proportion of workers in agriculture and plantation, mining, and manufacturing industry to the province's population is a proxy for economic activity in the province. This selection is because these three sectors are the main contributors to economic activities that use land. These variables represent how much the local government has given up its forest area used for economic activities, and these activities show the level of land demand in a province. These variables were expected to have a positive relationship with the increase of the deforested area.

The last variable is the population density as a proxy of the level of land requirement of an area that naturally occurs. The need for a living area cannot be restrained, and this shows a decisive factor besides economic factors in the need of land use in an area. This variable is calculated by dividing the total population by its area and expressed in people per square kilometer units. The total population was expressed in units of people, and the area was expressed in units of square kilometers. In the form of a fraction, the population density value is rounded up because there are no people valued at fractions. The increased value of this variable was expected to have a positive relationship with the deforestation rate. The summary of the variables used in this research showed in table 1.

Table 1 Descriptive Statistic of Dependent and Independent Variables

\begin{tabular}{lrrrrr}
\hline \multicolumn{1}{c}{ Variables } & Obs. & Means & Std. Dev. & Min & Max \\
\hline Deforested area & 363 & 18.3593 & 37.7070 & -14.8805 & 290.777 \\
Forest subsidy & 363 & .0108 & .0280 & 0 & .2114
\end{tabular}




\begin{tabular}{lrrrrr} 
New tariff policy & 363 & .5455 & .4986 & 0 & 1 \\
Agriculture and & 363 & .1813 & .0853 & .0015 & .5730 \\
Plantation worker & & & & & \\
Mining worker & 363 & .0101 & .0134 & .0011 & .0912 \\
Industry worker & 363 & .0428 & .0309 & .0035 & .2032 \\
Population density & 363 & 681.5096 & 2434.173 & 6 & 1590 \\
\hline
\end{tabular}

This panel data model aims to examine whether the forest subsidy and the rise of the logging tariff policy can curb the deforested areas in the province. This research employed a linear panel data model at the provincial level. Provinces as individuals are constant because the size does not change over time, and provinces have the same forest types according to the Ministry of Forestry standards. The panel data model is used to handle the heterogeneity and individual effect that may not be observed. The panel data model can examine group effects (individual-specific), time effects, or both.

The initial presumption is that Deforestation is influenced by Forest Subsidy, New tariff policy, Sectoral worker (Agriculture and Plantation; Mining, and Industry manufacture), and Population density. The condition of the panel data in this research is strongly balanced. Observations in the panel data model in this study amounted to $363(\mathrm{~N})$, where the period time was 11 years (T), start from 2009 to 2019 , and the number of groups was $33(\mathrm{n})$ provinces in Indonesia.

Panel data model test for group (individual-specific) effects, time effects, or both sequentially. This effect is in the form of a fixed effect or random effect. To deal with heterogeneity or personal effects that may or may not be observed, fixed effect models can test whether intercepts vary across groups or periods, whereas random-effects models explore differences in errors variant components across individuals or periods.

\section{Result and Analysis}

The output result of pooled OLS regression, over the dependent variable deforested area and six independent variables, are presented in table 2.

Table 2 The impact of Forest Subsidy on Deforested Area

\begin{tabular}{lrr}
\hline & Parameter estimates & $\begin{array}{c}\text { Standard } \\
\text { Error }\end{array}$ \\
\hline Forest subsidy given to the provincial government & $5.893^{* * *} *$ & 1.177 \\
Imposition of logging tariffs policy & 0.106 & 3.723 \\
Economic activities in Agriculture and Plantation & 0.003 & .002 \\
Economic activities in Mining sector & $0.272^{* * *}$ & .064 \\
Economic activities in Industry sector & $-0.015^{* * *}$ & .003 \\
Population density & -0.001 & .001 \\
Constanta & $7.185^{*}$ & 3.609 \\
\hline Observations & 330 & \\
R-squared & 0.2129 & \\
F-test (model) & $14.56^{* * *}$ & \\
\hline
\end{tabular}

$* \mathrm{p}<0.05, * * \mathrm{p}<0.01, * * * \mathrm{p}<0.001$

This pooled OLS model fits the data well. The F-test score of 14.56 is significant to reject the null hypothesis at the .01 significance level $(p<.0000)$. This means that, with 
this model, the independent variable can explain the effect of the relationship with the dependent variable. The $\mathrm{R} 2$ of .2129 means that this model accounts for 21 percent of the total variance in the deforested area of province forest management activities. This means that the overall model can explain as much as $21 \%$. The rest could be affected by other variables outside the model and must be the government's attention on controlling the problem of deforestation.

The forest subsidy variable has a coefficient of 5.893 at the .01 significance level. Furthermore, the mining and industrial manufacturing sector worker variable have a coefficient of 0.272 and -0.015 , respectively. Both variables, the mining, and the industrial manufacturing sector workers, are significant at the .01 level. Furthermore, the output shows that three out of the six independent variables, namely the forest subsidies, the mining sectors, and the industrial sector workers, affect the dependent variable significantly at .01 levels. However, the output result also shows that the variables imposition of the logging tariffs policy; the agriculture and plantation sector worker; and the population density, do not affect the deforested area at the significance level larger than $\alpha$.

The results of the analysis based on table 5.2 above can be interpreted in several points. First, in case of zero forest subsidy allocation and ignoring the increase in logging tariffs in 2014, there is no economic activities in agriculture and plantation sector. This condition applied to economic activities in the mining sector, the industrial manufacture sector, and a stable population density. Each province is expected to have 7.185 thousand hectares increase of the deforested area in a year $(\mathrm{p}<.047)$. This means that the government cannot just stand still and not control the deforested areas. Deforestation continues to occur and reduces the land cover or forest area of Indonesia. Concurrently, there are many factors, outside the variables used in the model, which also affect the deforested area, especially in terms of increasing its area.

Second, whenever the forest subsidy increases by one billion dollars, the province would experience an increase by 5.893 thousand hectares, holding all other variable constants $(\mathrm{p}<.000)$. These output results show unexpected results because the expectation from the central government in providing forest subsidy is a reduction in the deforested area. This is possible when there are other factors cause the forest subsidy. The subsidies, received by the provincial government, are not to have a negative impact on the deforested area. The transmission mechanism of providing forest subsidy to deforestation is quite long. Forest subsidy was used to carry out reforestation programs which are very much determined by decisions on development priorities in the region. Then, the implementation of the reforestation program was done, and it takes time to produce results in the form of new land cover plants. The choice of the planting site and the waiting time for plants can be calculated as part of the land cover, creating a delay in the recognition of new forests as the basis for calculating the deforested area.

Third, if the worker ratio of the mining sector increases by 1 unit, the deforested area will increase by 0.272 thousand hectares, holding all other variables constant $(\mathrm{p}<.000)$. This condition means that the economic activities in the mining sector have a positive impact on the addition of the deforested area. This result shows that the mining sectors are a true determinant of deforestation. This condition can be explained that the current technique of 
the mining industry in Indonesia requires land for its improvements. Whenever economic activities in this sector rise, it will cause an increase in deforestation.

Fourth, if the worker ratio of the industry manufacturing sector increases by 1 unit, the deforested area will decrease by 0.015 thousand hectares, holding all others variable constant $(\mathrm{p}<.000)$. This condition means that the economic activities in the manufacturing sector have a negative impact on the addition of the deforested area. This is also the result of unexpected output because, according to previous research, the industrial sector's economic activity is one of the causes of deforestation. This condition can be explained that the current development of the manufacturing industry in Indonesia does not necessarily lead to an increase in land requirements and an increase in forest logging activities. Economic activity in the industrial sector is one of the sectors, that can absorb workers who were previously in other sector activities, which are the cause of the high activity of deforestation.

Lastly, holding all variable constant, tariff policy $(\mathrm{p}<.0977)$, agriculture and plantation sector worker $(\mathrm{p}<.213)$, and population density $(\mathrm{p}<.448)$ does not significantly affect deforestation area. This output's result was slightly unpredictable because the increase is expected, as a policy of the central government, to reduce the deforested areas. This policy of increasing logging rates has a short transmission mechanism with deforestation. The new tariff for logging was expected to change forest management permit holders' decisions to reduce their logging activities. However, the change did not happen, and it did not affect the decisions because there might be other factors that were more decisive. For example, the decision of a forest management permit holder is a business decision that is very much determined by the market. If the demand from the market is high, both domestically and internationally, then the decision to carry out logging activities is more influenced by this factor.

The estimation results show unexpected results, where the forest subsidy has a positive impact, on the deforested area. The forest subsidy, that the central government hopes can reduce the deforested areas, has the opposite effect. This result is possible because there is an autocorrelation condition and endogeneity between variables. Many other factors influence the provincial government to use forest subsidies and carry out reforestation programs. A factor that may influence the independent variable is the decision of the head of regional to prioritize the economic activities program over reforestation. This decision may lead to an increase in the deforested area. The more significant economic activity reflects the greater the likelihood that deforestation will occur and is one of the considerations for the central government to provide greater forest subsidies to the provincial government.

Regarding the use of forest subsidies, local governments have absolute authority to implement the reforestation program using these funds. The decision to use forest subsidies cannot be captured by the model because other unobservable variables such as determining the priority of local government program activities and the decision of the head of regional. Moreover, implementing the reforestation program also did not provide sufficient incentives and disincentives for local governments to comply.

The program providing forest subsidy to run reforestation programs has undergone several changes. Starting from the recipient of subsidies initially the district or 
city government and changed by the provincial government. The program implements follow forest subsidy recipients where there is a change in the responsibility of program implementers of the district or city government to the provincial government. These changes are also related to changes in the policy of regulating land use designation, which originally existed with the district or city government to become the authority of the provincial government. The effects of these policy changes have never been thoroughly evaluated by ministries, both those related to forest management and those related to state finances.

The mining sectors worker shows that an increase in economic activities in the mining sectors will increase deforestation. The Indonesian mining sector still uses the "open pit" technique with land clearing as its main activity. This technique was used by almost all mineral mining companies in Indonesia. Until 2015, only one mine in Indonesia used the "deep mine" technique with tunnel excavation as its main activity. Accordingly, the growth in mining activities is in line with the growth in land clearing. This growth is what makes the mining sector one of the main factors of deforestation in Indonesia.

Mining companies operating in Indonesia use the open pit technique because it is much cheaper than the deep mining technique. The Indonesian government has never restricted open-pit mining techniques. As long as operating mining companies can provide reforestation program of the land they have cleared for mining, they will receive mining permission from the Indonesian government. In this case, the granting of mining permits lies with the forest management unit in the provincial government. The Indonesian government's policy towards the implementation of mining activities has not fully protected forest sustainability.

The industry-manufacturing sector worker shows unexpected results that harm the deforested area. As previously explained in the estimation results section above, an increase in economic activities in the manufacturing industry sector can reduce logging activities because it absorbs workers. The activities of the manufacturing industry, that requires wood raw materials from forests and new land activities, are increasing not in the type of industry. The displacement of economic sector activities, which are came from the side of workers, may cause changes in deforested area. Increasing manufacturing industry can also absorb labor, from the agriculture and plantation sector, as well as the mining sector. This condition is a decrease in activity, which makes logging activities decrease. This decrease is likely to reduce the deforested area.

The advancement of Indonesian technology in today's industrialized world has reduced land for factories and raw wood materials. Indonesia has started to implement strict regulations regarding land use for factories, and this seems to have succeeded in making innovations from producers to intensify production without adding new land. They can apply this on fixed land, but a new technology that does not require additional space in their production line. Next is the application of substitutes, for wood raw materials, which have begun to be applied in the Indonesian industrial world. A new type of raw material synthetic wood to replace natural wood opens new industrial opportunities in Indonesia. These two things make the increase in economic activities in the industrial sector not to increase the deforested areas, but instead can reduce the rate of deforested area. 
Another unexpected result comes from the new tariff policy. The output results show no effect of the tariff policy on the deforested area. This condition illustrates that the policy has no incentives and disincentives, that can influence on forest logging decisions. As mentioned before, regarding the policy of increasing logging tariff, the decisions to reduce logging activities are completely rests with the forest management permit holder. They include large agricultural, plantation, mining, and manufacturing industry owners. The consideration of reducing logging activities, which can reduce deforestation, is influenced by many other factors, such as business decisions; company profits and losses; and timber market demand.

The Indonesian government applies forest logging tariffs, in conjunction with the application of state revenues, from timber products. These two policies have opposite incentives, where one of the regulations facilitates logging activities, while the other provides resistance. The implementation of state regulations, on timber products, has prompted the government to encourage forest production. This effort will lead to an increase in state revenues and an increase in deforested areas. On the other hand, the implementation of the logging tariffs regulations was expected to reduce logging activities, and at the same time reduce the deforested area. There has been no publication from the government, particularly the Ministry of Forestry, which informs about evaluating the impact of these two regulations simultaneously.

As can be seen from the estimation results, economic activities in the agricultural and plantation sectors, and the mining sectors, unexpectedly do not have an influence on the deforested areas. In previous research findings, this sector is proven to contribute to land deforestation, empirically. This sector's activity is the main target of the tariff logging policy, and it is the government's concern in controlling deforestation. This situation can be explained by shows the manufacturing industry sector has a negative relationship with the deforested area.

The expansion of agricultural and plantation areas in Indonesia is still happening today. For example, the expansion of oil palm plantations and timber is the raw material for the Indonesian paper industry. Both of these plantation products are superior in quality and have become the leading commodities in the world market. Although it is always suspect and researched as the primary drivers of deforestation, the agricultural and plantation sectors have applied advanced agricultural technology. Progress, in the form of expansion of agricultural production with a land intensification system, has been introduced in Indonesia for a long time. It looks like that this progress has shown results with no more effect on deforested areas.

The next point, that can be discussed from the estimation results, was the unexpected result. It was unexpectedly that the population density does not affect the deforested area. Indonesia's development in providing housing for residents still embraces new land clearing for housing. It is only in recent years, that low-cost flats and apartments have been developed for the community. However, this condition has only happened in urban areas. Indonesia's condition still occurs with higher population density can add pressure to land requirements. This is a concern of the government when land requirements lead to deforestation. In addition, population density can also affect the high demands for economic activity by local governments. However, the government does not seem to worry anymore 
about population density. If the program of flats and cheap apartments for residents continues, it will be thriving.

Although the imposition of logging tariff policy variables does not affect the deforested area, the negative coefficient value of this variables can have the slightest effect that can reduce the deforested area. Then, for the variable imposition of logging tariff policy, its application is expected to reduce the growth of deforestation by 2.96 thousand hectares. The central government of Indonesia is still concerned about the sustainability of these policies. Perhaps the government could make this policy more effective with additional regulations, that clarify disincentives to continue logging activities, or otherwise provide incentives to reduce logging activities for forest management permit holders.

The explanation above can explain that this study still has limitations. The independent variable used to explain the relationship in the model is still affected by other factors. Information on unobservable variables that can affect independent variables takes a long time to collect and comes from many sources. This condition opens opportunities for subsequent research to enrich the types of variables, and control over existing relationships.

\section{Conclusion}

The findings show unexpected results from the interest variables. The analysis reveals that forest subsidy brings positive impacts, and tariff policy has no impact on the deforested areas. The length of the transmission mechanism from forest subsidy to the deforested areas may explain these findings. Forest subsidy will affect the willingness of the provincial government to undertake a reforestation program because it has funds to finance the program. If the program can be implemented, the program result can be obtained in the following years, as part of the calculation of deforestation areas. If the provincial government still prioritizes economic activities, it is unlikely that the reforestation program will be succeeded, and it will have an impact on the deforestation areas.

On the other hand, the imposition of tariff policy has a shorter transmission mechanism than the forest subsidy. The logging tariffs is directly imposed on forest management permit holders, who carry out forest logging activities. This study shows that there is no impact from the tariff policy on the deforested area because there were other factors, that were not captured in the model. This unexpected result occurs because the decision of the forest management permit holder is affected by other factors that were not explained in the model.

In the findings, the ratio of industry worker shows economic activities in the industry-manufacturing sector does matter on the deforested area. A significant result at the .01 level shows a considerable influence on the deforested area. Advances in the industrial technology and the labor market, in the industrial sector, may absorb a lot of work force. This condition has a negative effect and reduces the $\backslash$ deforested areas. This situation means that an increase in the activity of the industrial sector will reduce the deforested area.

In the findings on the mining workers sector, the ratio shows economic activities in this sector have a significant effect on the deforested area. The significant level shows a large positive influence on the deforested area. The mining techniques used do not support 
forest conservation; in fact, they almost certainly cause deforestation. This condition means that an increase in the activity of the mining sector will increase the deforested area.

The next finding, regarding the two economic sectors (agriculture-plantation) and population densities that do not affect the deforested area, may be relaxed by the government. The government still needs to control the increase in population density, which may naturally always affect the increase in the deforested area through the need for residential land. Providing residential land for residents is also one of the obligations of the Indonesian government. Therefore, the policy to control population density must be in line with the other policies regarding land use.

Based on the result and discussion, we propose some recommendations might be suitable to overcome deforestation in Indonesia. First, currently, the provision of forest subsidy is one way to repair existing forest damage. However, this policy needs a thorough evaluation. The central government needs to make concessions on how to use these funds, which are still related to forest improvement, to provide more incentives to the provincial government.

On the other hand, on the imposition of raising the logging tariffs that could not reduce logging activities, the central government seems to need to pay more attention to the demand for wood raw materials in the domestic market. The government needs to consider alternative solutions such as planting specific timber plants for industrial raw materials. For example, the forest management's permit holder must plant the same tree plants they are cutting or open a concession for the same crop type.

Then, closely related to logging activities by the wood industry, in general, the activities of the manufacturing industry also trigger deforestation. However, the government needs to pay more attention to improving the industrial sector with environmental and forest-friendly policies. The Indonesian government must also pay attention to the effectiveness of the mandatory reclamation policy by mining companies in Indonesia. The government should start thinking about limiting mining activities with open-pit techniques and encouraging mining companies to use deep mining techniques.

Last but not least, the central government has included aspects of climate change that are closely related to deforestation into national development priorities. It is to hope that this can be continued down to the provincial government level so that it also gives priority to development programs with aspects of climate change and always places reforestation programs as one of the priority activities. This is because local governments play a strategic role in improving the economic welfare of the community. Therefore, it is appropriate for local governments to ensure inclusive development and include an agenda for maintaining environmental quality and addressing climate change by prioritizing reforestation programs. 


\section{Reference}

Adrison, Vid. 2013. Deforestation in Decentralized and Democratic Indonesia. Working paper, Institute for Economic and Social Research, Faculty of Economic and Business, University of Indonesia, Jakarta.

Anastatica, Yolanda. 2020. Do Forest Management Unit and Special Allocation Grants Reduce Deforestation in Indonesia? An Empirical Test. Master's thesis, International University of Japan. Niigata, Japan.

Andersen, Lykke E. 1996. The Causes of Deforestation in the Brazilian Amazon. Journal of Environment and Development 5 (3): 309-28. https://doi.org/10.1177/107049659600500304.

Anugrah, Nunu. 2020a. Deforestation Decreases, Indonesia Receives USD 103.8 Million from the GCF. Press Conference Number: SP. 354 / HUMAS / PP / HMS. http://ppid.menlhk.go.id/siaran_pers/browse/2627. (accessed August 3, 2020).

2020b. SOFO 2020: Indonesia's Deforestation Drops Sharply, Jokowi Government's Commitment to Protect Biodiversity. PRESS RELEASE NUMBER: SP. 213/PR/PP/HMS. http://ppid.menlhk.go.id/siaran_pers/browse/2486. (accessed May 3, 2020).

Ashton, Mark S., C. V.S. Gunatilleke, I. A.U.N. Gunatilleke, B. M.P. Singhakumara, Sunil Gamage, Tomohiro Shibayama, and Chisato Tomimura. 2014. Restoration of Rain Forest beneath Pine Plantations: A Relay Floristic Model with Special Application to Tropical South Asia. Forest Ecology and Management 329: 351-59. https://doi.org/10.1016/j.foreco.2014.02.043.

Balooni, Kulbhushan, and Makoto Inoue. 2007. Decentralized Forest Management in South and Southeast Asia. Journal of Forestry 105 (8): 414-20. https://doi.org/10.1093/jof/105.8.414.

Bettwy, Mike, Tropical Deforestation Affects Rainfall in the U.S. and Around the Globe. News Magazine - Feature (blog), NASA, September 13, 2015, https://www.nasa.gov/centers/goddard/news/topstory/2005/deforest_rainfall.ht ml. (accessed December 3, 2020).

Boucher, Doug, Sarah Roquemore, and Estrellita Fitzhugh. 2013. Brazil's Success in Reducing Deforestation. Tropical Conservation Science 6 (3): 426-45. https://doi.org/10.1177/194008291300600308.

Burgess, Robin, Matthew Hansen, Benjamin A. Olken, Peter Potapov, and Stefanie Sieber. 2012. The Political Economy of Deforestation in the Tropics. Quarterly Journal of Economics 127 (4): 1707-54. https://doi.org/10.1093/qje/qjso34.

Erwinsyah, Erwinsyah, Harianto Harianto, Bonar M. Sinaga, and Bintang C.H. Simangunsong. 2013. Dampak Kebijakan Provisi Sumberdaya Hutan Dan Dana Reboisasi Terhadap Kesejahteraan (Impact of Provision of Forest Resources Policy and Reforestation Fund on Welfare). Jurnal Analisis Kebijakan Kehutanan (Journal of Forestry Policy Analysis) $10 \quad$ (1): $15-36$. https://doi.org/10.20886/jakk.2013.10.1.15-36.

Evans, Megan C. 2018. Effective Incentives for Reforestation: Lessons from Australia's Carbon Farming Policies. Current Opinion in Environmental Sustainability 32 (October 2017): 38-45. https://doi.org/10.1016/j.cosust.2018.04.002.

Godar, Javier, Toby A. Gardner, E. Jorge Tizado, and Pablo Pacheco. 2014. Actor-Specific Contributions to the Deforestation Slowdown in the Brazilian Amazon. Proceedings 
of the National Academy of Sciences of the United States of America 111 (43): 1559196. https://doi.org/10.1073/pnas.1322825111.

Gonschorek, Gerrit J., and Günther G. Schulze. 2018. Continuity or Change? Indonesia's Intergovernmental Fiscal Transfer System under Jokowi. Journal of Southeast Asian Economies 35 (2): 143-64. https://doi.org/10.1355/ae35-2c.

Hargrave, Jorge, and Krisztina Kis-Katos. 2013. Economic Causes of Deforestation in the Brazilian Amazon: A Panel Data Analysis for the 2000s. Environmental and Resource Economics 54: 471-94. https://doi.org/10.1007/s10640-012-9610-2.

Indonesia, Statistics. 2020. Deforestation Rate (Netto) in Indonesia, Inside and Outside Forest Area 2013-2018 (Ha/Year). Indonesia Deforestation Book 2013-2014, 20142015, 2015-2016, 2016-2017, Ministry of Environment and Forestry. 2020. https://www.bps.go.id/statictable/2019/11/25/2081/angka-deforestasi-nettoindonesia-di-dalam-dan-di-luar-kawasan-hutan-tahun-2013-2018-ha-th-.html.

Irawan, Silvia, Luca Tacconi, and Irene Ring. 2013. Stakeholders' Incentives for Land-Use Change and REDD+: The Case of Indonesia. Ecological Economics 87: 75-83. https://doi.org/10.1016/j.ecolecon.2012.12.018.

Princeton University-Research Reports. 2013. If a Tree Falls in Brazil...? Amazon Deforestation Could Mean Droughts for Western U.S. by Kelly, Morgan, U.S. 2013. https://www.princeton.edu/news/2013/11/07/if-tree-falls-brazil-amazondeforestation-could-mean-droughts-western-us? section=topstories.

Mildrayana, Eri. 2012. The Socio-Economic Factors on Deforestation in Indonesia. Master's thesis, International University of Japan. Niigata, Japan.

Nepstad, Daniel, David McGrath, Claudia Stickler, Ane Alencar, Andrea Azevedo, Briana Swette, Tathiana Bezerra, et al. 2014. Slowing Amazon Deforestation through Public Policy and Interventions in Beef and Soy Supply Chains. Science 344 (6188): 111823. https://doi.org/10.1126/science.1248525.

Ostrom, Elinor. 2000. Collective Action and the Evolution of Social Norms. Journal of Economic Perspectives 14 (2000): 137-58. https://doi.org/10.1257/jep.14.3.137.

President Indonesia, The Republic of Indonesia. 1999. Kehutanan (Forestry). Indonesia.

- 2020. Rehabilitasi Dan Reklamasi Hutan (Forest Rehabilitation and Reclamation). Indonesia. LN.2020/NO.137, TLN NO.6518, JDIH.SETNEG.GO.ID : 28 HLM.

Robbins, Jim, Deforestation and Drought. Opinion (News Analysis-blogs), New York Times, October 9, 2015, https://www.nytimes.com/2015/10/11/opinion/sunday/deforestation-anddrought.html. (accessed December 3, 2020)

Statistics Indonesia. 2020. Forest Area and Conservation Waters Area of Indonesia Based on Decree of the Minister of Environment and Forestry until December 2018. Statistics of the Ministry of Environment and Forestry 2018. 2020. https://www.bps.go.id/statictable/2013/12/31/1716/luas-kawasan-hutan-dankawasan-konservasi-perairan-indonesia-berdasarkan-surat-keputusan-menterilingkungan-hidup-dan-kehutanan-s-d-desember-2018.html.

Susetyo, Pramono Dwi. 2021. Sampai Dimana Rehabilitasi Hutan? (Where Does Forest Rehabilitation Go?). Laman Kabar Baru (News Update Page). 2021. https://www.forestdigest.com/detail/996/perbedaan-reforestasi-reboisasirehabilitasi-penghijauan. (accessed March 15, 2021).

I. A.P. Resosudarmo, W.D. Sunderlin. Rates and Causes of Deforestation in Indonesia: A Review of Confusion and Solutions (Laju Dan Penyebab Deforestasi Di Indonesia: 
Penelaahan Kerancuan Dan Penyelesaiannya). CIFOR Occasional Working Paper No.9 (I). Center for International Forestry Research, Bogor, Indonesia, March 1997. https://doi.org/10.17528/cifor/000057.

Yazid, Muhammad. 2020. Do Plantation Commodity as Main Income Influence Deforestation? Evidence from Village Level in Indonesia. Master's thesis, International University of Japan. Niigata, Japan. 